\title{
Tail myology and flight behaviour: Differences between caracaras, falcons and forest falcons (Aves, Falconiformes)
}

\author{
María Clelia Mosto $^{1}$ (D) | Mariana Beatriz Julieta Picasso ${ }^{1}$ | Martín Miguel Montes $^{2}$ | \\ Oliver Krone ${ }^{3}$
}

\author{
${ }^{1}$ Museo de La Plata-Facultad de Ciencias \\ Naturales y Museo, Universidad Nacional \\ de La Plata- CONICET, Buenos Aires, \\ Argentina \\ ${ }^{2}$ CEPAVE -CONICET Centro de Estudios \\ Parasitológicos y de Vectores- Universidad \\ Nacional de La Plata, Buenos Aires, \\ Argentina \\ ${ }^{3}$ Leibniz Institute for Zoo and Wildlife \\ Research, Berlin, Germany

\section{Correspondence} \\ María Clelia Mosto, Museo de La \\ Plata-Facultad de Ciencias Naturales y \\ Museo, Universidad Nacional de La Plata- \\ CONICET, Buenos Aires, Argentina. \\ Email: cleliamosto@gmail.com
}

\begin{abstract}
Caracaras, falcons and forest falcons, which are representative of the three subfamilies of the family Falconidae, have different flight behaviour. Since, during flight, the tail works in coordination with the wings, the tail muscles could be indicative of the type of flight behaviour. The aim of this work was to describe in detail the littleknown tail muscles of the Falconidae and to explore their possible association with this different behaviour, by using the muscle mass as an indicator. To this end, the tail muscles of 18 specimens representing the three subfamilies of Falconidae were dissected, weighed and their percentage to the body mass calculated. The possible differences in tail muscle mass between Falconinae and Polyborinae were explored with a Bayesian statistical approach. In all species, the muscles depressor caudae and levator caudae had the highest mass values $(0.028 \%-0.329 \%$ and $0.120 \%$ $0.274 \%$, respectively), in accordance with the key movements performed during flight, that is, the tail depression and elevation. The total muscle masses of Falconinae and those of Polyborinae were significantly different $(p<0.05)$. This difference can be related with the different flight behaviour of falcons and caracaras, that is, fast and erratic flight, respectively.
\end{abstract}

\section{K E Y W O R D S}

diurnal raptors, locomotion

\section{1 | INTRODUCTION}

Given its importance in animal life, locomotion is a behaviour with great influence on animal morphology, ecology and physiology (Dickinson et al., 2000). Skeletal muscles, together with the skeletal system, are the motor and lever that make an animal move (Kardong, 2011; Wolff, 1991). Muscles play different roles, which can be seen reflected in their structure, from the sarcoplasm to the whole muscle (Gans \& Gaunt, 1991). For example, walking and running birds have hind limbs with well-developed extensor muscles, which provide body support and propel the body forward (Hutchinson, 2004; Mosto, Carril, \& Picasso, 2013; Picasso,
2010; Picasso, Tambussi, Mosto, \& Degrange, 2012; Smith, Wilson, Jespers, \& Payne, 2006), whereas aerial feeding birds, like certain oscines, have muscle features that favour flexion and adduction of their hind limbs, which is aerodynamically advantageous during flight (Moreno \& Carrascal, 1993).

The tail of birds is a unique locomotor region due to its intimate association with wings and because both work in coordination during flight (Felice \& O'Connor, 2014; Gatesy \& Dial, 1993, 1996; Videler, 2006). It is a peculiar structure (Videler, 2006) that consist of, externally, the feathers (rectrices) that are supported, internally, by an oval structure named bulbus rectricium, which is located on each side of the pygostylus 
(Baumel et. al., 1993; Zusi \& Bentz, 1984). This bulbus rectricium is formed by muscular, connective and adipose tissues. The remaining components of the tail are the free caudal vertebrae and the muscles (Baumel et al., 1993; Gordon, Blickhan, Dabiri, \& Videler, 2017; Videler, 2006). Among other functions, the tail performs an aerodynamic function, so its external shape is variable according to the aerodynamic properties and, in consequence, to the bird's ecology and flight behaviour (Felice \& O'Connor, 2014; Thomas, 1993). Indeed, most studies of the tail in birds focus on its aerodynamic function (e.g., Thomas, 1993, Thomas, 1996a, 1996ba,b), setting aside the study of the internal morphology like the musculature or the skeleton. As an exception, the study of Felice and O'Connor (2014) explored the morphology of the pygostyle in underwater foraging birds. The tail of birds is moved by the action of a few and poorly studied muscles (Gordon et al., 2017; Raikow, 1985; Videler, 2006), which are independent of the trunk and hindlimb muscles, allowing the specific control of the rectrices (Gatesy \& Dial, 1993).

Previous studies have only described the muscles (George \& Berger, 1966; Zusi \& Bentz, 1984) or explored the complete morphology of the tail (Baumel, 1988) or the pattern of electrical activity of the muscles (Gatesy \& Dial, 1993, 1996). In the past, a few studies have vaguely explored the variation in the tail bird musculature in taxa with different flight behaviour (Fisher, 1946; Owre, 1967). More recently, the work of Moreno and Møller (1996) was the only one that provided quantitative information with an ecological interpretation in swallows (Hirundinidae, Passeriformes). The family Falconidae, which has three recognised subfamilies (Polyborinae, Falconinaeand Herpetotherinae) (Fuchs, 2015; Fuchs, Johnson, \& Mindell, 2012), is a diverse lineage of diurnal raptors that shows diversity in their flight behaviour. The Falconinae (falcons) are cosmopolitan aerial predators that pursuit their prey at high speeds (Sustaita, 2008; White et al., 1994); the Polyborinae (caracaras) are neotropical generalists that have a slow and erratic flight and commonly walk on the ground looking for their prey (Fuchs et al., 2012; Sustaita, 2008; White et al., 1994; Winkle et al., 2015); and the Herpetotherinae (forest and laughing falcons) are neotropical birds that inhabit humid forests and little is known about their behaviour (White et al., 1994; Winkler, Billerman, \& Lovette, 2015). Regarding the latter, it has been reported that Micrastur spp., among which $M$. ruficollis is the best-known species, are agile flyers among the foliage (Canevari, Carrizo, \& Canevari, 1991) that hunt insects and small birds and reptiles from perchs or on the ground, and that Herpetotheres cachinnans hunts mainly snakes (Costa, Lopes, Freitas Marçal, $\&$ Zorzin, 2014). Previous studies have demonstrated that the Falconidae - at least falcons and caracaras-show morphological features in their locomotor system that are related with the locomotor behaviour. Terrestrial caracaras have elongated hindlimbs with predominance of extensor musculature (Mosto et al., 2013; Mosto, Picasso, \& Biondi, 2016), whereas falcons are powerful fast-flying birds, whose wings show greater muscle mass than those of caracaras (Picasso \& Mosto, 2018) and whose legs have a powerful flexor muscle in their digits (Mosto, 2017). Thus, it is possible to wonder whether the muscle features of the tail of the Falconidae can be linked to their flight behaviour. In these raptors, the internal morphology of the tail is almost unknown, with only two studies performed more than 40 years ago: that of Jollie (1977), who presented a brief and undetailed description of some muscles of the tail, and that of Richarson (1972), who briefly described the presence of accessory bones present in the pygostyle. Thus, new and updated information is necessary to increase the morphological knowledge of these birds. The aim of the present study is to provide a complete description of the tail musculature of the Falconidae and to explore whether the muscle mass might be related with the different types of flight behaviour of the most terrestrial raptors (Polyborinae) and the most aerial ones (Falconinae).

\section{2 | MATERIALS AND METHODS}

\section{1 $\mid$ Specimens}

A total of 18 specimens representing the three subfamilies of the Falconidae were studied (Supporting Information Table S1): eight Polyborinae (Caracara plancus-crested caracara-, Milvago chimango-chimango caracara-, and M. chimachima-yellow headed caracara-); nine Falconinae (Falco peregrinus-peregrine falcon-, F. sparveriusAmerican kestrel-, F.femoralis- aplomado falcon-, $F$. subbuteo-Eurasian hobby- and F. tinnunculus-common kestrel-); and one Herpetotherinae (Micrastur ruficollisbarred forest falcon-).

The origin of the materials is multiple (Supporting Information Table S1). Specimens with the acronym IZW belong to the Leibniz Institute for Zoo and Wildlife Research in Berlin, Germany, an institution that receives carcasses from donations or confiscations, which are available for research. Specimens with the acronym MLP (Colección anexa de la División Paleontología Vertebrados, Museo de La Plata) come from La Marcela farm (26 $\left.17035^{\prime \prime} \mathrm{S} ; 59^{\circ} 06,067^{\prime \prime} \mathrm{W}\right)$, Pirané, Formosa Province, Argentina, with authorization of the Ministerio de la Producción y Ambiente, Dirección de Fauna y Parques of Formosa province, Argentina (guía de tránsito $n^{\circ}$ 003384), and from Buenos Aires province, Argentina: Programa de Control de Aves en Rellenos Sanitarios y Áreas Aledañas (ProCoA).The specimen of Micrastur ruficollis was killed accidentally on a road of the Iguazú National Park, Misiones Province, Argentina (Administración de Parques Nacionales, $\mathrm{PN}^{\circ}$ 1380). 


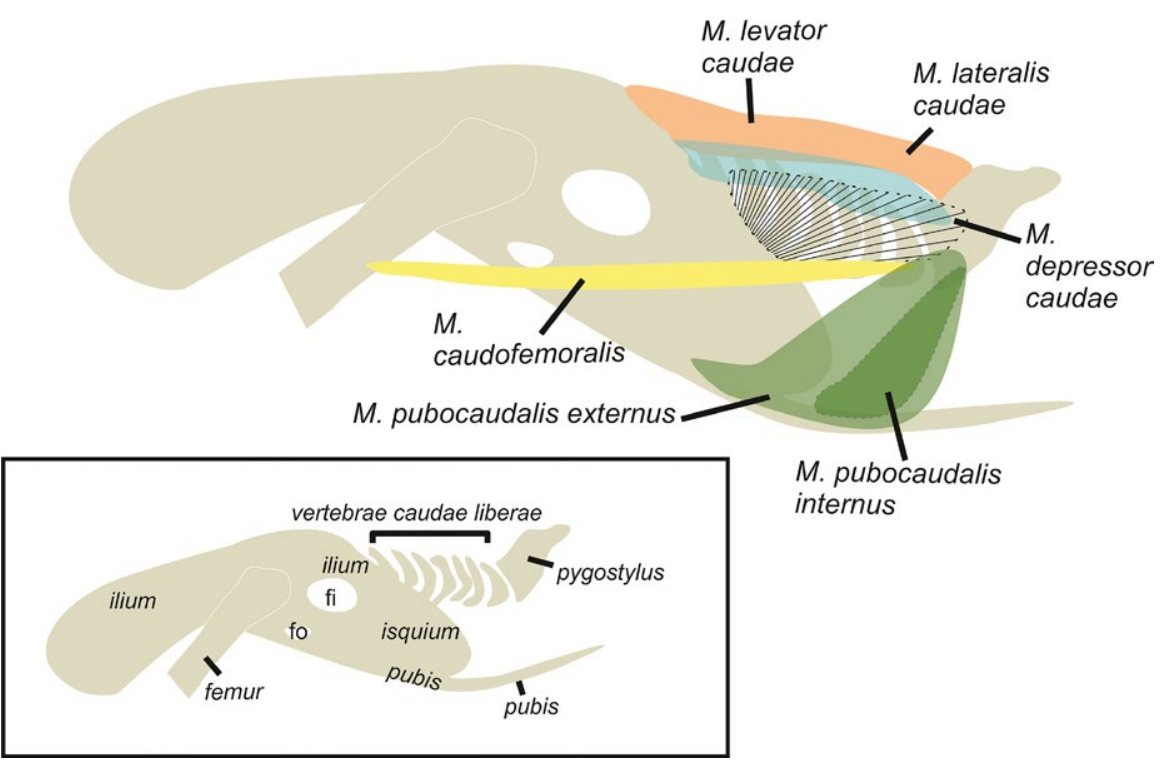

F I G URE 1 Schematic drawings showing the approximate position of the muscles with respect to the skeleton. In the box is the detailed osseous regions of pelvis, caudal vertebrae and pygostylus [Colour figure can be viewed at wileyonlinelibrary. com]

\section{4 | Data analysis}

The muscle mass is proportional to the maximum muscle power output (Biewener \& Roberts, 2000; Roberts, 2001) and several studies have shown that great muscular masses are related with the main role that muscles perform during locomotion (e.g., Hartman, 1961; Hutchinson, 2004; Mosto, 2016; Picasso, 2015). Thus, we here compared the Falconinae and Polyborinae by using the tail muscle mass as an indicator of its possible relationship with the type of flight. We used a Bayesian approach, with normal and noninformative prior distribution, to calculate the $95 \%$ Bayesian Credible Intervals (95\%BCIs) with the mean and the 2.5th and 97.5th percentiles of the distribution for each tail muscle and the total tail muscles of the Falconinae and Polyborinae. Differences were identified when BCIs did not overlap and/ or $p$-value was $<0.05$. The software WinBUGS 1.4.3 (Lunn, Thomas, Best, \& Spiegelhalter, 2000) (https://www.mrc-bsu. cam.ac.uk/software/bugs/) was used to generate 100,000 samples from the posterior distributions for each of the analyses after discarding the initial 10,000 samples as "burn in". The Bayesian statistical approach is progressively being used in many fields of science (Ellison, 2004; Silva \& Benavidez, 2001; Wade, 2000), offering an alternative to analyse data with small samples (Lee \& Song, 2004; Wade, 2000). The Bayesian approach is based on the posterior distribution where the parameters are random quantities (Stokes, Chen \& Gunes, 2014) (in classical statistics, the parameters of interest respond to a fixed model of distribution). Thus, in the BCIs, the mean of a posterior distribution is the estimate of the parameter and its percentiles provide the credible intervals (Stokes et al., 2014). The $p$-values for each pair of individual muscles and for the total muscle mass were performed with the Bayesian Module in the EPIDAT software (https:// www.sergas.es/Saude-publica/EPIDAT-4-2). 


\section{\begin{tabular}{l|l}
3 & RESULTS
\end{tabular}}

\section{1 $\quad$ Muscle description}
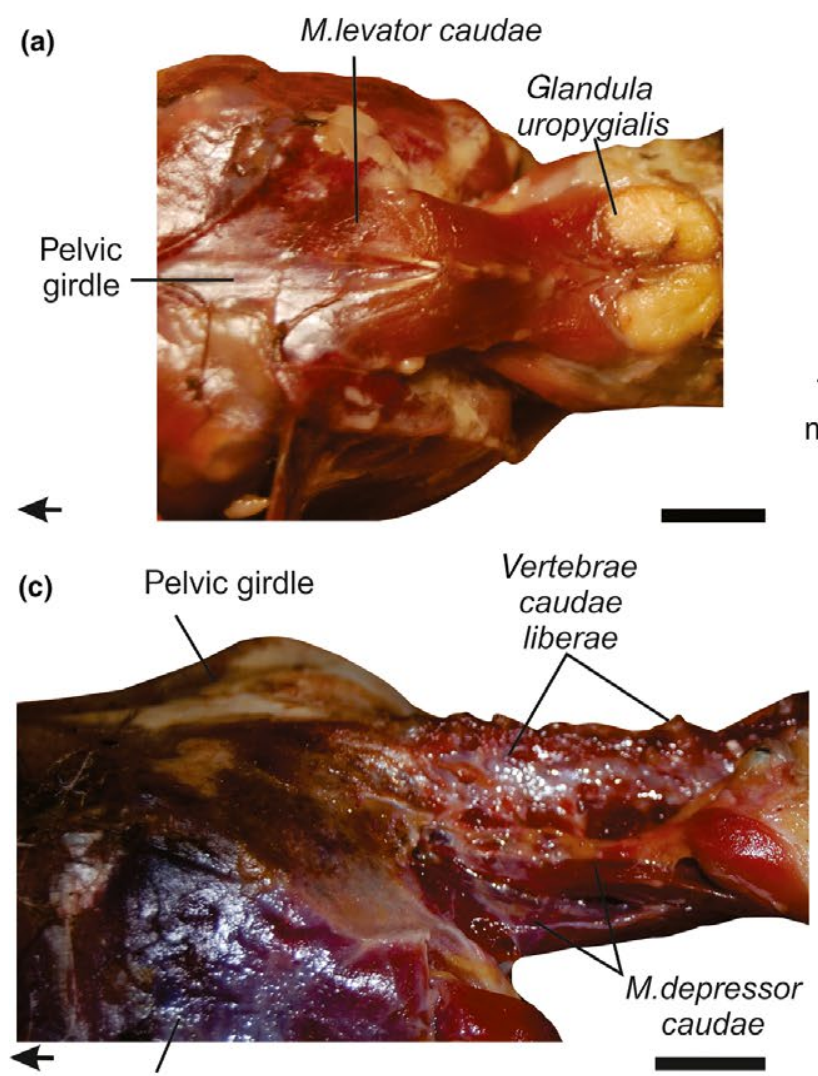

Thigh muscles

(e)

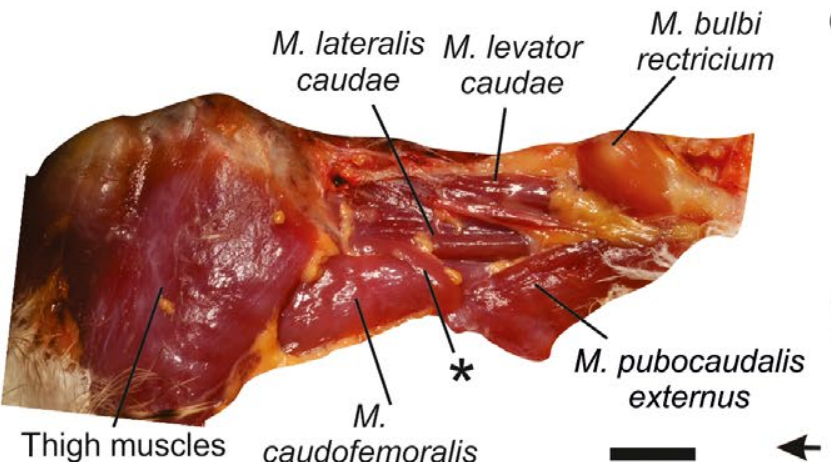

(g)

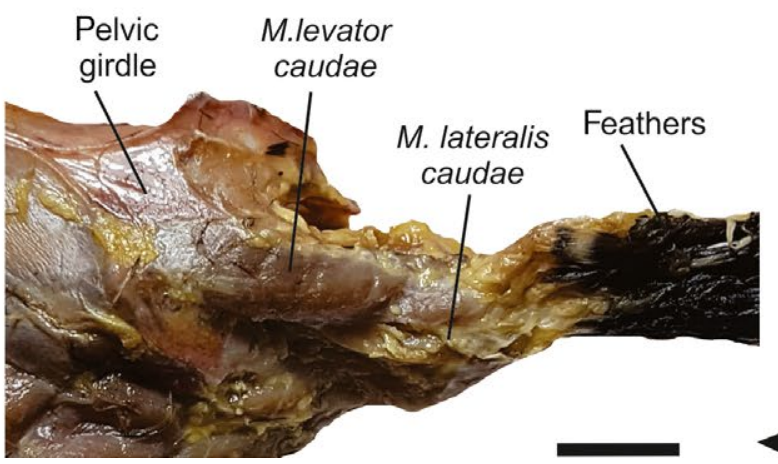

The m. levator caudae (Figure 2a,b) only had the pars vertebralis. It is a fleshy muscle that originates on the dorsal surface of the mid-posterior part of the postacetabular ilium and
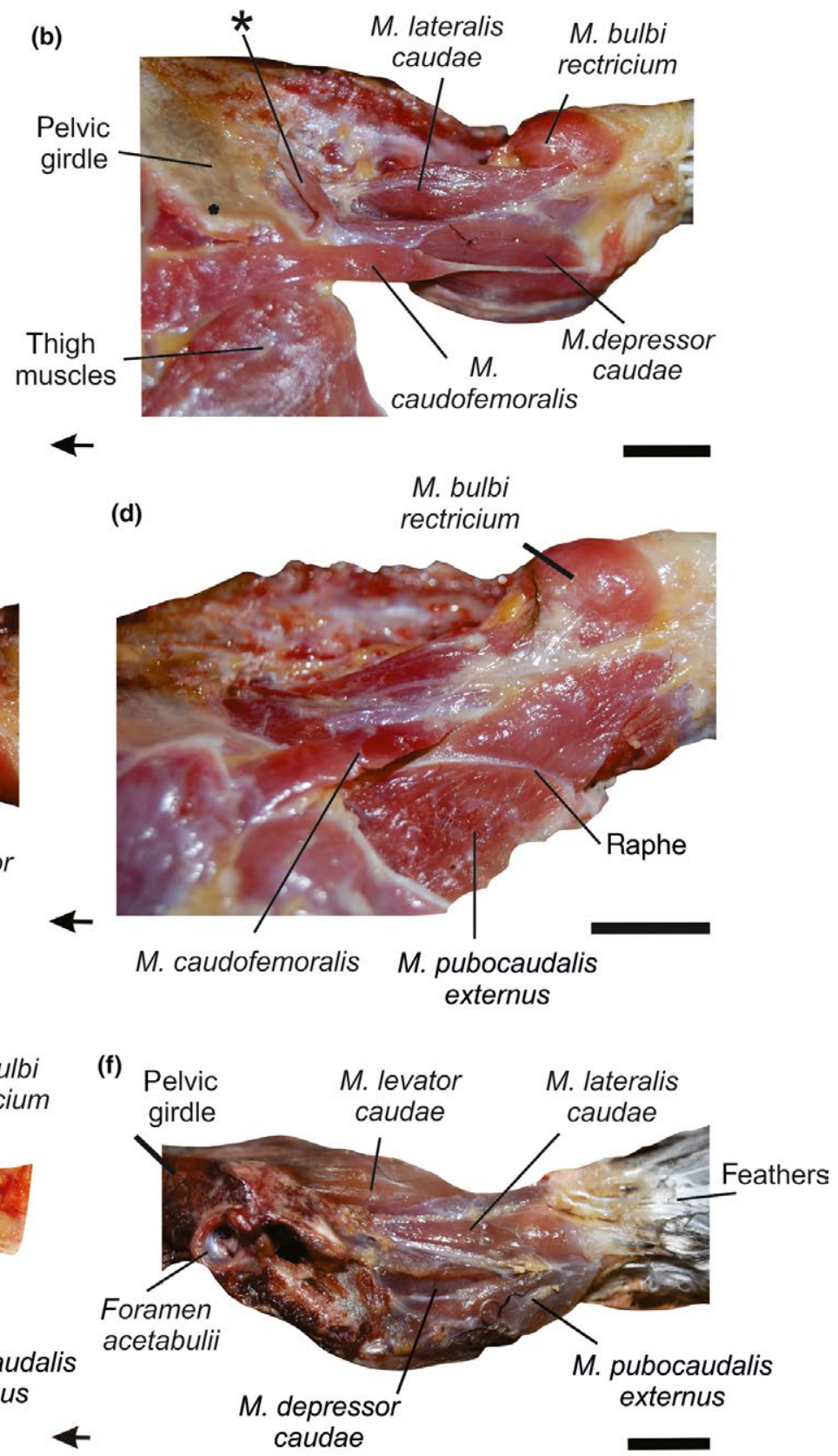

(h)

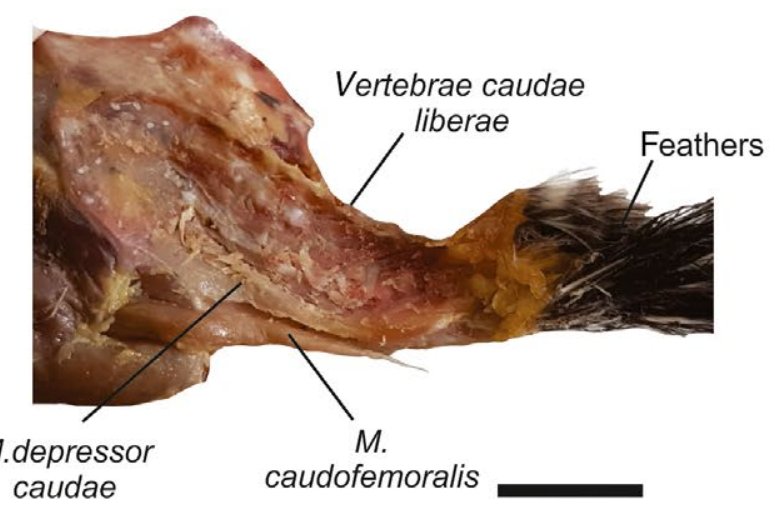


F I G U RE 2 Gross morphology of the tail muscles (a) Dorsal view of Milvago chimango showing the m. levato rcaudae and the posterior region of the pelvis, (b) Lateral view of Caracara plancus with the mm. levator caudae and pubocaudalis externus remove, (c) Lateral view of tail of Caracara plancus showing two portions of the m. depressor caudae, (d) Detailed view of the m. pubocaudalis internus of Caracara plancus showing their raphe, (d) lateral view of the tail muscles of Falco peregrinus, (e) lateral view of the tail muscles of Falco femoralis with the $m$. caudofemoralis removed and showing the $m$. depressor caudae, $(\mathrm{g})$ and (h) lateral view of the tail muscles of Micrastur ruficollis with the muscles removed partially and showing the $\mathrm{mm}$. levator caudae and lateralis caudae (g) and the mm. caudofemoralis (partially removed) and depressor caudae (h).The arrow indicates the cranial direction. The $(*)$ indicate the " $m$. transversus cloacae" (see text for details). Scale bar: $1 \mathrm{~cm}[$ Colour figure can be viewed at wileyonlinelibrary.com]

synsacrum. Once this muscle is removed, it leaves a welldistinguished impression (Figure 3a,b). It inserts into the conjunctive tissue of the bulbus rectricium. Also, the muscle gives off several small tendons which attach on the processus spinosus of each vertebra caudalis libera. In Micrastur (Figure $2 \mathrm{~g}, \mathrm{~h}$ ), the muscle has a second small fleshy portion that originates on the dorsal surface of the processus transversus of the last three vertebrae caudales liberae and inserts into the bulbus rectricium.

The $\mathbf{m}$. lateralis caudae (Figure $2 \mathrm{~b}, \mathrm{e}, \mathrm{f}, \mathrm{g}$ ) originates fleshy from the processus transversus of the first three vertebrae caudales liberae and on a small area on the caudal margin of the ilium (Figure 3b). The muscle inserts fleshy into the conjunctive sheet of the external rectrices.

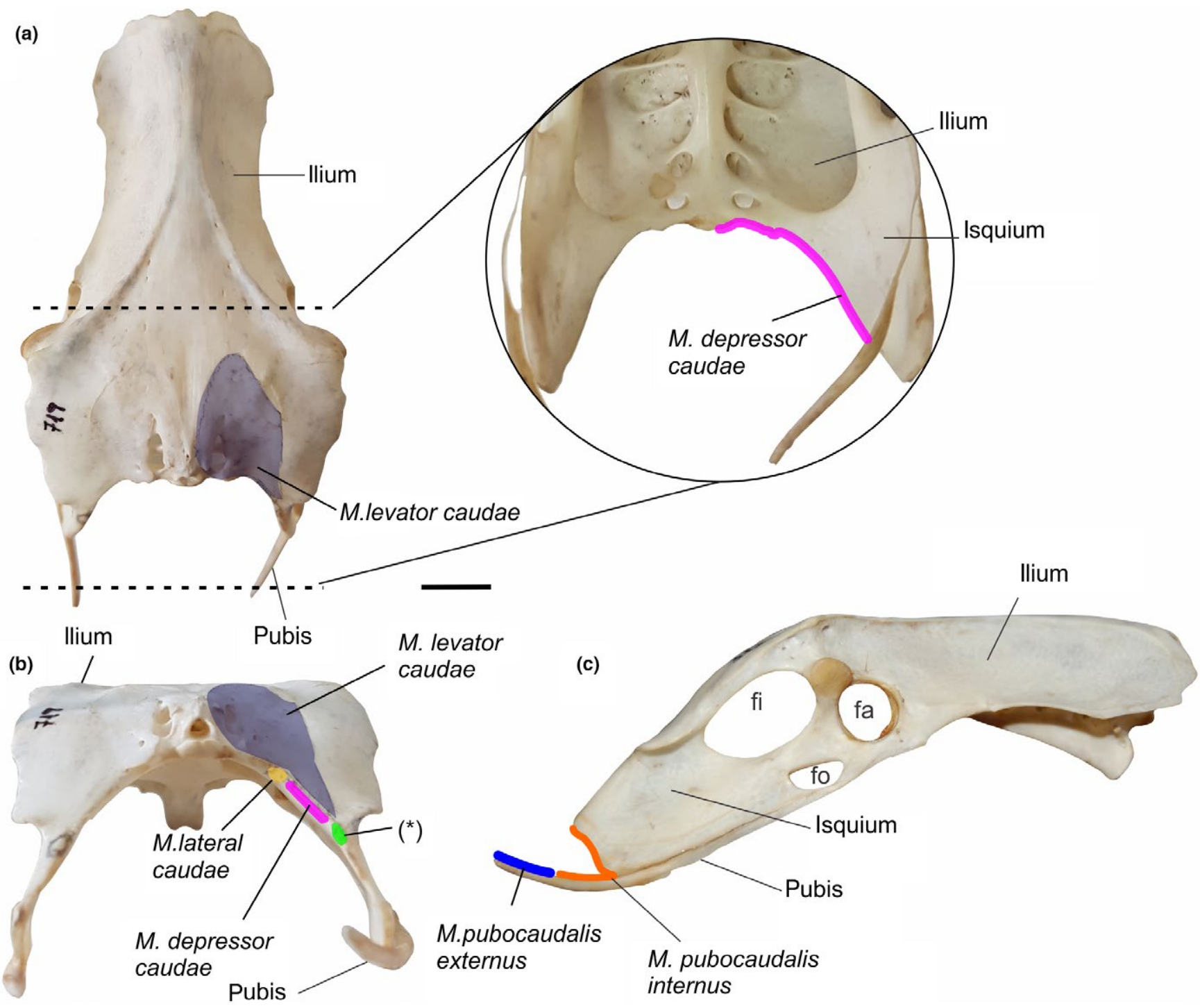

F I G U R E 3 Muscular maps showing the muscular origins on the pelvis, using the pelvis of Caracara plancus as example (MLP 719), (a) dorsal view and ventral view (box) (b) caudal view, (c) lateral view. The (*) indicate the origin of the "m. transversus cloacae" (see text for details). Scale bar: $1 \mathrm{~cm}$ [Colour figure can be viewed at wileyonlinelibrary.com] 
The $\boldsymbol{m}$. pubocaudalis externus (Figure 2e,f) is a flat muscle that originates fleshy on the distal third of the pubis (Figure 3c) and inserts, also fleshy, into the conjunctive sheet of the outermost rectrix feather. It is intimately related with the M. pubocaudalis internus.

The m. pubocaudalis internus (Figure 2d) is a flat muscle with a fleshy origin on the internal aspect of the pubis and the caudal margin of the ala ischii (Figure 3c). It inserts into the ventral surface of the conjunctive sheet of the rectrices and into the basis pygostyli. In Caracara plancus, this muscle has a tendinous raphe in the middle of the belly.

The m. caudofemoralis (Figure 2b,d,e,h) only has the pars caudalis, while the pars pelvica is absent. It is a straplike muscle that originates by a small tendon on the aponeurosis cruciata. The muscle tapers and gives rise to a short tendon that inserts into the caudal proximal half of the diaphysis of the femur. In Falco and Micrastur, the tendon of origin arises from the ventral surface of the accessory bones of the pygostylus.

The m. depressor caudae (Figure 2b,c,f,h) is a complex muscle with several portions and the largest muscle of the tail. In Milvago, Micrastur and Falco, the muscle has two portions. In Milvago, both portions originate fleshy on the posterior edge of the ilium Figure $3 \mathrm{~b}$ ) and insert into the conjunctive sheet of the rectrices. In Micrastur ruficollis, the origin of both portions is similar to that of those of Milvago, but instead, the sites of insertion are different. The superficial portion inserts fleshy into the basis pygostyli, whereas the deep one inserts into the accessory bones. In
Falco species, the superficial portion originates from the ventral surface of the processus transversus of the free caudal vertebrae and inserts fleshly into the basis pygostyli. The deep portion originates from the caudal margin of the ilium (Figure 3a) and from the ventral surface of the processus transversus of the first two vertebrae caudales liberae. The muscle inserts by a tendon into the bulbus rectricium.

In Caracara plancus, the $m$. depressor caudae has three portions. The most superficial one originates fleshy along the ventral surface of the processus transversus of the vertebrae caudales liberae and inserts into the ventral surface of the conjunctive sheet of the rectrices. The intermediate portion originates fleshy on the first vertebra caudalis libera and inserts into the conjunctive sheet of the rectrices. The deep portion originates fleshy on the caudal margin of the ilium and ischium (Figure 3a). The insertion of this belly is by a tendon into the bulbus rectricium.

The $\boldsymbol{m}$. bulbi rectricium (Figure $2 \mathrm{~b}-\mathrm{e}$ ) is a wide and flat muscle that envelops the sheet of connective tissue of the rectrices. This muscle showed no noticeable differences between the birds studied.

In Caracara plancus and Falco species, there is a small thin band-like muscle (Figure 2b,e) with a tendinous origin on the caudal edge of the ilium, next to the origin of the deep portion of the $m$. depressor caudae, and a fleshy insertion into the belly of the $m$. pubocaudalis externus. This muscle is located over the $m$. caudofemoralis and is visible when the $m$. levator caudae is removed. It could be the dorsal portion of the $m$. transversus cloacae (see Discussion section). (a)

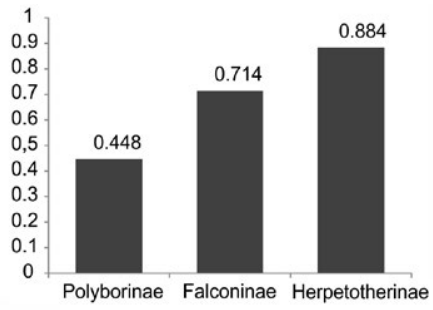

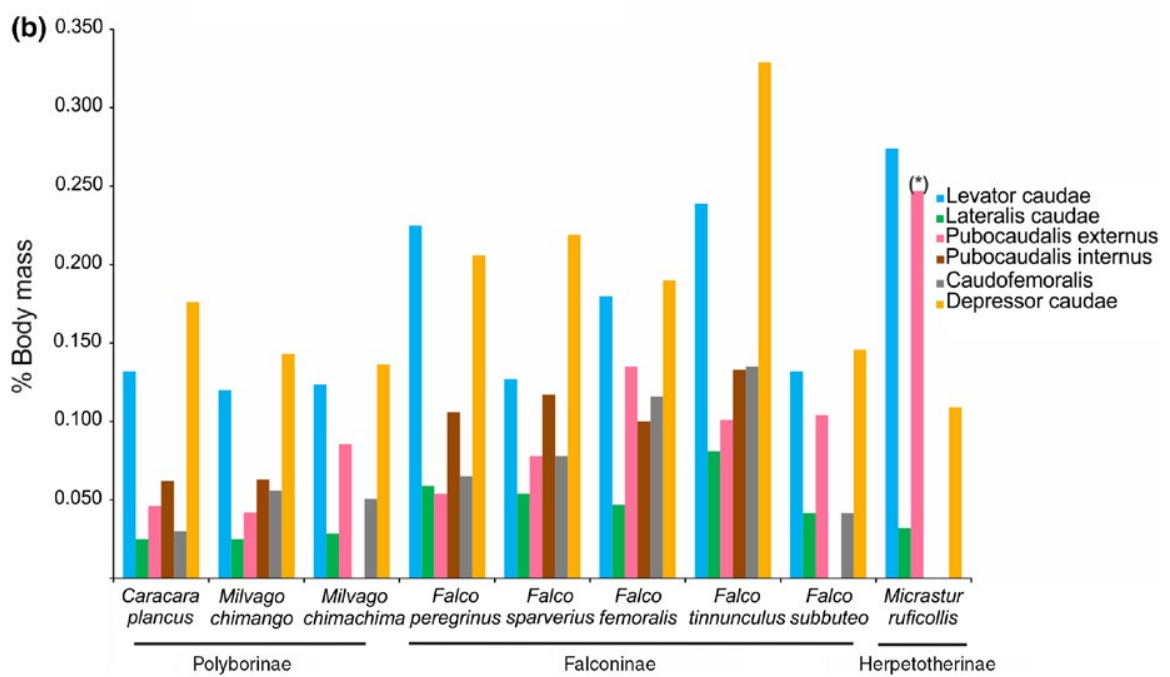

F IG URE 4 Bar graphic showing the percentages of the muscles with respect to the body mass, (a) The total tail muscle mass in each subfamily, (b) the individual muscle mass in each species study. Note the high values of mm. levator caudae and depressor caudae [Colour figure can be viewed at wileyonlinelibrary.com] 


\section{2 | Muscle mass}

The total muscle mass of the tail with respect to the body mass ranged between $0.448 \%$ and $0.884 \%$ among the subfamilies (Figure 4a). The highest proportions were found in Micrastur ruficollis $(0.884 \%)$ and in the falconines $(0.714 \%)$, whereas the lowest values were found in the polyborines $(0.448 \%)$ (Figure 4a, Supporting Information Table S2).

Regarding individual muscles, the $\mathrm{mm}$. depressor caudae and levator caudae were the ones with the highest proportion of body mass, with values that ranged between $0.028 \%-0.329 \%$ and $0.120 \%-0.274 \%$, respectively (Figure 4b, Supporting Information Table S2). Instead, in Falco peregrinus and Micrastur ruficollis, the $m$. levator caudae was the only one with the highest proportion (Figure $4 \mathrm{~b}$, Supporting Information Table S2). The m. pubocaudalis internus was the third largest muscle (0.062\%-0.133\%), except in F. femoralis, where the $m$. pubocaudalis externus was heavier than the $m$. pubocaudalis internus (Figure $4 \mathrm{~b}$, Supporting Information Table S2). The remaining muscles had a lower proportion that ranged from $0.024 \%$ to $0.146 \%$ (Figure 4b, Supporting Information Table S2). The credible intervals of the total muscle masses of Falconinae and those of Polyborinae were significantly different ( $p<0.05$, Figure 5 Supporting Information Table S3). Regarding the analysis of the individual muscles, only the mm. levator caudae, pubocaudalis externus and lateralis caudae were different between the two subfamilies $(p<0.05)$ (Figure 5, Supporting Information Table S3).

\section{4 | DISCUSSION}

The tail myology is a promising field of study that may contribute to detecting the association between morphological and ecological characteristics and may help to understand how morphology influences bird life (Dial, 2003; Wainwright, 1996).

In the present study, the gross anatomical features of the tail muscles found in Falconidae were very similar to those of other birds (Baumel, 1988; Baumel et al., 1993; George \& Berger, 1966; Raikow, 1985; Zusi, 1985; Zusi \& Bentz, 1984). The tail muscles were characterised by the predominance of fleshy origins and insertions and bellies with a fusiform or band-like aspect. Also, the muscles with single bellies were common, except for the $m$. depressor caudae, which showed two or more bellies. The muscle identified as "transversus cloacae" remains to be confirmed. The muscle most similar to this one is the dorsal part of the m. transversus cloacae described for the Trochilidae (hummingbirds) (Zusi $\&$ Bents, 1984). In these birds, the origin of the dorsal portion is similar to those of Caracara plancus and Falco, but the insertion is into the wall of the cloaca (Zusi \& Bents, 1984). Instead, in C. plancus and Falco, the insertion is into the $m$. pubocaudalis externus and would not have direct action in the movement of the cloaca.

The pattern of mass values of each tail muscle was similar in all the species studied, being the $m$. depressor caudae the most well-developed muscle, followed by the m. levator caudae. Their greater masses suggest that the depression and elevation of the tail are key movements in tail performance and that the remaining muscles with lower mass perform accessory roles assisting in the movements of depression, rotation or rectricial spread (Raikow, 1985). Comparison with other birds is difficult due to the scarcity of similar data. However, Moreno and Møller (1996) found a similar pattern in the muscle mass in Hirundinidae (swallows) because they found that the $m$. depressor caudae and the $m$. levator caudae were the muscles with greater mass. These authors concluded that the $m$. depressor caudae is crucial to counteract

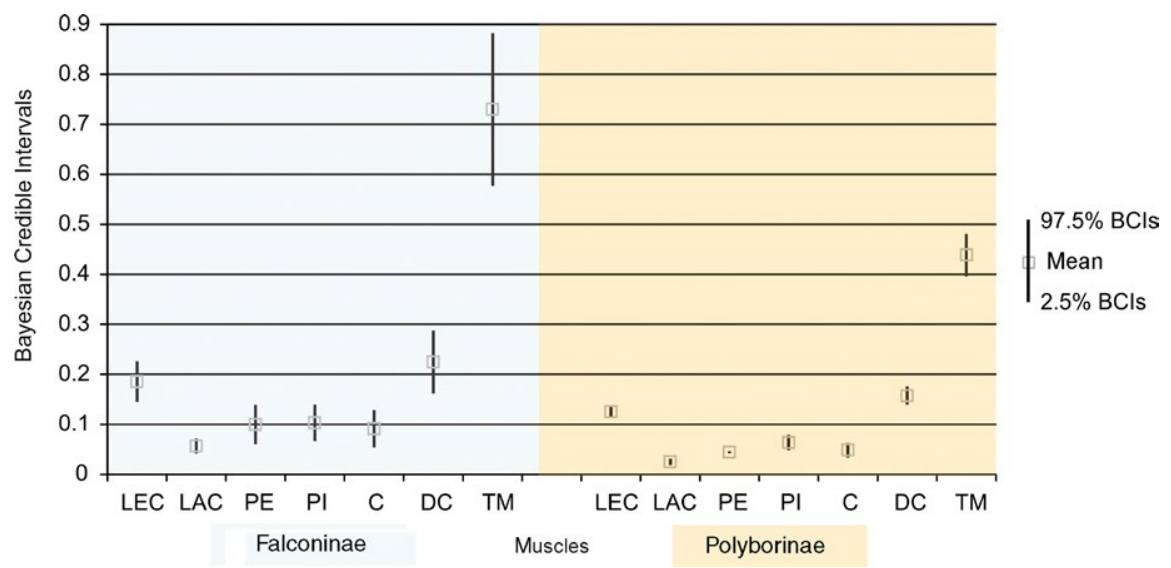

F I G U RE 5 Box plot showing the BCIs for each muscle and for the total tail muscle mass (TM) in Falconinae and Polyborinae. Abbreviations: LEC: $m$. levator caudae, LAC: $m$. lateralis caudae, PE: m. pubocaudalis externus, PI: m. pubocaudalis internus, C: $m$. caudofemoralis, DC: $m$. depressor caudae [Colour figure can be viewed at wileyonlinelibrary.com] 
the upward action of the air on the tail surface (Moreno \& Møller, 1996), which could be true not only for swallows but also for Falconidae.

Several muscles (levator caudae, lateralis caudae, and pubocaudalis externus) showed greater mass in falcons than in polyborines. It is possible to infer that, in falcons, this could be related with their agile and fast flight, but the absence of studies that relate tail movements and muscle activity prevents reaching a more detailed conclusion. Interpretations are also hampered by the fact that some of these muscles perform other functions. As an example, the m. levator caudae is also active while walking (Gatesy \& Dial, 1993) and both mm. pubocaudales are involved in the respiratory movements along with the m. caudofemoralis (Baumel, Wilson, \& Bergren, 1990).

Falcons and caracaras showed different values in their total tail muscle masses, which might be indicative of their importance in flight behaviour. The greater proportion of tail muscle mass in falcons could be related with their fast flight, since this may contribute to improving their agility and the role of the tail: as a rudder when the bird is turning or for control of pitching movements (Raikow, 1985; Videler, 2006). Instead, the relatively lower value of tail muscle mass of caracaras can be related with their slow and erratic flight (Ferguson-Lees \& Christie, 2001; White et al., 1994). Although speculative, the great tail muscle mass of Micrastur ruficollis may be related with the great manoeuvrability of its flights (Canevari et al., 1991), a skill needed to fly in dense forest (Thomas \& Balmford, 1995).

Integrating this information with previous studies, a different set of morphological features related with the locomotor apparatus can be recognised among the Falconidae members. Caracaras, which are opportunistic and terrestrial, are known by their long legs and great muscle mass useful for hind limb extension, which is necessary for an efficient walk on the ground (Mosto, 2017; Mosto et al., 2013, 2016). Compared with falcons, caracaras have a smaller proportion of wing musculature (Picasso \& Mosto, 2018) and relatively low values of tail muscle mass (this study). In contrast, falcons are powerful flyers with short legs and a relative higher mass in several grip-flexor muscles (Mosto, 2017; Mosto et al., 2013, 2016). Compared with caracaras, falcons have a great muscle proportion in their wings (Picasso \& Mosto, 2018) and tail (this study). Finally, Micrastur ruficollis is an agile flyer in dense forests (Canevari et al., 1991), with high values of tail muscle mass similar to those of Falco species. It has long hindlimbs (similar to those of the Polyborinae) with values of muscle mass higher than those of the Polyborinae and Falconinae, which could be related to its hunting behaviour (Mosto, 2017; Mosto et al., 2013). The results of the present study may hopefully contribute to a better understanding of the tail myology in birds and its association with the different types of flight behaviour.

\section{ACKNOWLEDGMENTS}

This work was supported by Fondo para la Investigación Científica y Tecnológica (FONCyT): PICT 2016-4615 and the German Academic Exchange Service (DAAD). We also like to thank to Guillermo Gil, Susanne Auls and Yolanda Davies.

\section{ORCID}

María Clelia Mosto (D) https://orcid.org/0000-0002-1927-3602

\section{REFERENCES}

Baumel, J. J. (1988). Functional morphology of the tail apparatus of the pigeon (Columba livia). Advances in Anatomy, Embryology, and Cell Biology, 110, 1-115.

Baumel, J. J., King, S. A., Breazile, J. E., Evans, H. E., \& Berge, J. C. (1993). Handbook of Avian Anatomy: Nomina Anatomica Avium. Cambridge: Publication 23 of Nuttall Ornithological Club.

Baumel, J. J., Wilson, J. A., \& Bergren, D. R. (1990). The ventilatory movements of the avian pelvis and tail: Function of the muscles of the tail region of the pigeon. Journal of Experimental Biology, 151, 263-277.

Biewener, A. A., \& Robert, T. J. (2000). Muscle and tendon contributions to force, work and elastic energy savings: A comparative perspective. Exercise and Sport Sciences Reviews, 2803, 99-107.

Canevari, M., Carrizo, G. R., \& Canevari, P. (1991). Nueva guía de las aves argentinas. Buenos Aires: Fundación Acindar.

Costa, H. C., Lopes, L. E., de Freitas Marçal, B., \& Zorzin, G. (2014). The reptile hunter's menu: A review of the prey species of Laughing Falcons, Herpetotheres cachinnans (Aves: Falconiformes). NorthWestern Journal of Zoology, 10, 443-453.

Dial, K. P. (2003). Evolution of avian locomotion: Correlates of flight style, locomotor modules, nesting biology, body size, development, and the origin of flapping flight. The Auk, 120, 941-952. https://doi. org/10.2307/4090265

Dickinson, M. H., Farley, C. T., Full, R. J., Koehl, M. A. R., Kram, R., \& Lehman, S. (2000). How animals move: An integrative view. Science, 288, 100-106. https://doi.org/10.1126/science.288.5463.100

Dunning, J. B. (2007). Handbook of avian body masses. Boca Raton: CRC Press.

Ellison, A. M. (2004). Bayesian inference in ecology. EcologyLetters, 7, 509-520. https://doi.org/10.1111/j.1461-0248.2004.00603.x

Felice, R. N., \& O'Connor, P. M. (2014). Ecology and caudal skeletal morphology in birds: The convergent evolution of pygostyle shape in underwater foraging taxa. PLoS ONE, 9(2), e89737. https://doi. org/10.1371/journal.pone.0089737

Ferguson-Lees, J., \& Christie, D. A. (2001). Raptors of the World. New York: Houghton Mifflin Company.

Fisher, H. I. (1946). Adaptations and comparative anatomy of the locomotor apparatus of New World vultures. American Midland Naturalist, 35, 545-727. https://doi.org/10.2307/2421553

Fuchs, J., Johnson, J. A., \& Mindell, D. P. (2015). Rapid diversification of falcons (Aves: Falconidae) due to expansion of open habitats in the Late Miocene. Molecular Phylogenetics and Evolution, 82, 166-182. https://doi.org/10.1016/j.ympev.2014.08.010 
Fuchs, J., Johnson, J. A., \& Mindell, D. P. (2012). Molecular systematics of the caracaras and allies (Falconidae: Polyborinae) inferred from mitochondrial and nuclear sequence data. Ibis, 154, 520-532.

Gans, C., \& Gaunt, A. S. (1991). Muscle architecture in relation to function. Journal of Biomechanics, 24, 53-65. https://doi. org/10.1016/0021-9290(91)90377-Y

Gatesy, S. M., \& Dial, K. P. (1993). Tail muscle activity patterns in walking and flying pigeons (Columba livia). Journal of Experimental Biology, 176, 55-76.

Gatesy, S. M., \& Dial, K. P. (1996). From frond to fan: Archeopteryx and the evolution of short-tailed birds. Evolution, 50 , 2037-2048.

George, J. C., \& Berger, A. J. (1966). Avian myology. New York: Academic Press.

Gordon, M. S., Blickhan, R., Dabiri, J. O., \& Videler, J. J. (2017). Animal Locomotion: Physical Principles and Adaptations. Boca Raton: CRC Press.

Hartman, F. A. (1961). Locomotor mechanisms of birds. Smithsonian Miscellaneous Collections, 143, 1-91.

Hutchinson, J. R. (2004). Biomechanical modelling and sensitive analysis of bipedal running ability I. Extant taxa. Journal of Morphology, 262, 421-440.

Jollie, M. T. (1977). A contribution to the morphology and phylogeny of the Falconiformes. Evolutionary Theory, 3, 1-141.

Kardong, K. V. (2011). Vertebrates: Comparative anatomy, function, evolution. New York: McGraw-Hill.

Lee, S. Y., \& Song, X. Y. (2004). Evaluation of the Bayesian and maximum likelihood approaches in analyzing structural equation models with small sample sizes. Multivariate Behavioral Research, 39, 653-686. https://doi.org/10.1207/ s15327906mbr3904_4

Lunn, D. J., Thomas, A., Best, N., \& Spiegelhalter, D. (2000). WinBUGS -a Bayesian modelling framework: Concepts, structure, and extensibility. Statistics and Computing, 10, 325-337.

Moreno, E., \& Carrascal, L. M. (1993). Ecomorphological patterns of aerial feeding in oscines (Passeriformes: Passeri). Biological Journal of the Linnean Society, 50, 147-165. https://doi. org/10.1111/j.1095-8312.1993.tb00922.x

Moreno, E., \& Møller, A. P. (1996). Morphological aspects of avian tail movements: A functional approach in Hirundines. The Auk, 113, 647-654. https://doi.org/10.2307/4088985

Mosto, M. C. (2017). Comparative hindlimb myology within the family Falconidae. Zoomorphology, 136, 241-250. https://doi.org/10.1007/ s00435-017-0343-1

Mosto, M. C., Carril, J., \& Picasso, M. B. J. (2013). The hindlimb myology of Milvago chimango (Polyborinae, Falconidae). Journal of Morphology, 274, 1191-1201.

Mosto, M. C., Picasso, M. B. J., \& Biondi, L. M. (2016). Long-legged caracaras: Terrestrial habitat and hindlimb morphology. Journal of Zoology, 298, 274-284. https://doi.org/10.1111/jzo.12313

Owre, O. T. (1967). Adaptations for locomotion and feeding in the Anhinga and the Double-crested Cormorant. Ornithological Monographs, 6, 1-138. https://doi.org/10.2307/40166666

Picasso, M. B. J. (2010). The hindlimb muscles of Rhea americana (Aves, Palaeognathae, Rheidae). Anatomia, Histologia, Embryologia, 39, 462-472. https://doi.org/10.1111/j.1439-0264.2010.01017.x

Picasso, M. B. J. (2015). Ontogenetic scaling of the hind limb muscles of the greater rhea (Rhea americana). Anatomia, Histologia, Embryologia, 44, 452-459.
Picasso, M. B. J., \& Mosto, M. C. (2018). Wing myology of Caracaras (Aves, Falconiformes): Muscular features associated with flight behavior. Vertebrate Zoology, 68, 177-190.

Picasso, M. B. J., Tambussi, C., Mosto, M. C., \& Degrange, F. J. (2012). Crecimiento de la masa muscular del miembro posterior del Nandú Grande (Rhea americana) durante la vida postnatal. Revista Brasileira De Ornitologia, 20, 1-7.

Raikow, R. J. (1985). Locomotor system. In A. S. King, \& J. McLelland (Eds.), Form and Function in Birds, Vol. 3 (pp. 57-147). London: Academic Press.

Richardson, F. (1972). Accessory pygostyle bones of Falconidae. Condor, 74, 350-351. https://doi.org/10.2307/1366597

Roberts, T. J. (2001). Muscle force and stress during running dogs and wild turkeys. Bulletin of the Museum of Comparative Zoology, 156, 283-295.

Silva, L. C., \& Benavides, A. (2001). El enfoque bayesiano: Otra manera de inferir. Gaceta Sanitaria, 15, 341-346. https://doi.org/10.1016/ S0213-9111(01)71578-6

Smith, N. C., Wilson, A. M., Jespers, K. J., \& Payne, R. C. (2006). Muscle architecture and functional anatomy of the pelvic limb of the ostrich (Struthio camelus). Journal of Anatomy, 209, 765-779. https://doi.org/10.1111/j.1469-7580.2006.00658.x

Stokes, M., Chen, F., \& Gunes, F. (2014). An introduction to Bayesian analysis with SAS/STAT software. In Proceedings of the SAS Global Forum 2014 Conference, SAS Institute Inc, Cary, USA, 1-25 (available at https://support.sas.com/resources/papers/proceedings14/ SAS400-2014.pdf).

Sustaita, D. (2008). Musculoskeletal underpinnings to differences in killing behavior between North American accipiters (Falconiformes: Accipitridae) and falcons (Falconidae). Journal Morphology, 269, 283-301. https://doi.org/10.1002/jmor.10577

Thomas, A. L. (1993). On the aerodynamics of birds' tails. Philosophical Transaction of the Royal Society of London B, 340, 361-380.

Thomas, A. L. (1996a). Why do birds have tails? The tail as a drag reducing flap, and trim control. Journal of Theoretical Biology, 183, 247-253.

Thomas, A. L. (1996b). The flight of birds that have wings and a tail: Variable geometry expands the envelope of flight performance. Journal of Theoretical Biology, 183, 237-245.

Thomas, A. L., \& Balmford, A. (1995). How natural selection shapes birds' tails. American Naturalist, 146, 848-868.

Videler, J. J. (2006). Avian flight. New York: Oxford University Press.

Wade, P. R. (2000). Bayesian methods in conservation biology. Conservation Biology, 14, 1308-1316. https://doi. org/10.1046/j.1523-1739.2000.99415.x

Wainwright, P. C. (1996). Ecological explanation through functional morphology: The feeding biology of sunfishes. Ecology, 77, 13361343. https://doi.org/10.2307/2265531

White, C. M., Olsen, P. D., \& Kiff, L. E. (1994). Family Falconidae (falcons and caracaras). In J. delHoyo, A. Elliott, \& J. Sargatal (Eds.), Handbook of the birds of the World, Volume. 2: New World Vultures to Guinea fowl (pp. 216-277). Barcelona: Lynx Editions.

Winkler, D. W., Billerman, S. M., \& Lovette, I. J. (2015). Bird families of the world: An invitation to the spectacular diversity of birds. Barcelona: Lynx Editions.

Wolff, R. G. (1991). Functional chordate anatomy. Massachusetts: D.C Heath and Company.

Zusi, R. L. (1985). Muscles of the neck, trunk and tail in the noisy scrub-bird, Atrichornis clamosus, and superb lyrebird, Menura 
novaehollandiae (Passeriformes: Atrichornithidae and Menuridae). Records of the Australian Museum, 37, 229-242.

Zusi, R. L., \& Bentz, G. D. (1984). Myology of the purple-throated carib (Eulampis jugularis) and other hummingbirds (Aves: Trochilidae). Smithsonian Contribution to Zoology, 385, 1-69. https://doi. org/10.5479/si.00810282.385

\section{SUPPORTING INFORMATION}

Additional supporting information may be found online in the Supporting Information section at the end of the article.
How to cite this article: Mosto MC, Picasso MBJ, Montes MM, Krone O. Tail myology and flight behaviour: Differences between caracaras, falcons and forest falcons (Aves, Falconiformes). Acta Zool. 2019;00:1-10. https://doi.org/10.1111/azo.12294 